\section{Menn med malignt melanom}

Dødeligheten av malignt melanom synker hos kvinner, men ikke blant menn (Arch Dermatol 2009; 145: 397-404). I en studie fra USA av mer enn 200 middelaldrende menn med malignt melanom har man nå unders $ø$ kt hva som karakteriserte pasienter med langtkommen sykdom Itumortykkelse $>2 \mathrm{~mm}$ ) versus de øvrige.

Mennene med langtkommen sykdom hadde færre atypiske nævi, visste mindre om sykdommen, og var mindre interessert $i$ helse enn de andre. Derimot fant man ingen korrelasjon mellom tumorstørrelse og alder, lokalisasjon eller toleranse for soleksponering. Gruppen som helhet hadde liten kunnskap om symptomer, og færre enn $20 \%$ brukte Internett som informasjonskilde.

\section{Cox-2 spiller en rolle i kreftutvikling}

Det er kjent at samspillet mellom stroma og epitel er viktig i utviklingen av brystkreft, men de bakenforliggende molekylære prosessene har til nylig vært ukjente. En ny studie har nå vist at COX-2-proteinet spiller en rolle i utvikling og progrediering av brystkreft (Proc Natl Acad Sci USA 2009; 106: 3372-7).

Forskergruppen benyttet musemodeller og fant at oppregulering av COX-2 resulterte $\mathrm{i}$ tumorvekst. Ved å gi musene celecoxib, ble COX-2 hemmet, og mus med forstadier til kreft (DCIS) utviklet ikke kreft. COX-2 ble uttrykt av tumorepitelceller ved kontakt med stromaceller, og dette ble mediert via NFkB-reaksjonsveien. Hemming av denne reaksjonsveien kan benyttes $i$ behandling og forebygging av brystkreft, konkluderer forfatterne.

\section{Gutter i faresonen for selvmord}

En finsk studie av hvordan psykiske symptomer hos barn kan forutsi senere selvmord og selvmordsforsøk er den første i sitt slag i verden (Arch Gen Psychiatry 2009; 66: 398-406): Over 5000 barn født i 1981, samt deres foreldre og lærere, svarte på spørreskjemaer da barna var åtte år gamle. Spørsmålene dekket vanlige psykiske lidelser latferdsforstyrrelser og depresjon), familieforhold og skoleprestasjoner. I løpet av 16 års oppfølgingstid begikk til sammen 16 personer selvmord, men bare to av disse var jenter. Litt mer enn dobbelt så mange hadde alvorlige selvmordsfors $ø$.

Blant guttene hadde $80 \%$ av dem som begikk selvmord psykiske lidelser som åtteåringer - som regel en kombinasjon av depresjon og atferdsforstyrrelse. Hos jentene var det derimot ingen sammenheng mellom psykiske plager som barn og selvmord eller selvmordsfors $ø$. Resultatene bekrefter tidligere funn om klare kjønnsforskjeller både når det gjelder prevalens av og risikofaktorer for selvmord.

\title{
Assosiasjon eller kausalitet?
}

\section{I en svensk studie er det påvist sam- menheng mellom en type Parecho- \\ virus og misdannelser i sentralnerve- systemet hos mus og mennesker.}

Ljunganvirus tilhører slekten Parechovirus og ble første gang påvist hos klatremus (Myodes glareolus) nær elven Ljungan i Midt-Sverige i slutten av 1990-årene. Det kan forårsake myokarditt, diabetes og encefalitt hos disse musene og gi dødelige perinatalinfeksjoner hos avkommet. Videre er det observert hydrocephalus og anencefali hos infiserte nyfødte mus.

Studier i Sverige har vist en assosiasjon mellom antall tilfeller av intrauterin fosterdød hos menneske og forekomst av smågnagere. En svensk forskergruppe har dessuten påvist Ljunganvirus i hjernevev og placenta fra noen intrauterint døde fostre, men ikke i et kontrollmateriale (1). Med immunhistokjemi og polymerasekjedereaksjon har nå gruppen undersøkt forekomsten av Ljunganvirus hos fostre fra elektive aborter (2). Det ble påvist virus i hjernevev eller hjertevev i ni av ti tilfeller med hydrocephalus og i ett av 18 kontrollfostre med trisomi 21. Hos fem av ni tilfeller med anencefali ble det påvist virus, men ikke hos noen av de 21 kontrollfostrene.

Forfatterne postulerer en mulig sammenheng mellom infeksjon med Ljunganvirus i svangerskapet og forekomsten av hydrocephalus og anencefali hos menneske. Mange infeksiøse agenser har vært assosiert med intrauterin fosterdød uten at man sikkert har kunnet vise en etiologisk sammenheng. Ennå vet vi lite om utbredelsen av viruset blant smågnagere $\mathrm{i}$ andre land, og om det dreier seg om lokale zoonoser eller om en mer endemisk utbredelse. Det er derfor viktig at tilsvarende studier gjøres $i$ andre land for å undersøke et større materiale og etterprøve funnene.

\section{Svein Arne Nordbø}

svein.a.nordbo@ntnu.no

Det medisinske fakultet

Norges teknisk-naturvitenskapelige universitet

\section{Litteratur \\ Niklasson B, Samsioe A. Papadogiannakis N et al. Association of zoonotic Ljungan virus with intra- uterine fetal deaths. Birth Defects Res A Clin Mol Teratol 2007; 79: 488-93. \\ 2. Niklasson B, Samsioe A, Papadogiannakis $\mathrm{N}$ et al. Zoonotic Ljungan virus associated with central nervous system malformations in terminated pregnancy. Birth Defects Res A Clin Mol Teratol 2009; doi: 10.1002/bdra.20568.}

\section{Sen oppstart med fysisk aktivitet er også gunstig}

Menn som starter å trene etter fylte

50 år kan bedre leveutsiktene i samme grad som påvist ved røykeslutt.

Det er velkjent at fysisk aktivitet har gunstig helseeffekt. Nå har svenske forskere studert hvordan endring i fysisk aktivitet hos middelaldrende menn påvirker mortalitet (1).

2205 menn som var 50 år i 1970-73, ble undersøkt frem til 82-årsalderen. Relativ reduksjon i mortalitetsrate ved høy fysisk aktivitet var i utgangspunktet $32 \%$ og $22 \%$ sammenliknet med hhv. lav og middels aktivitet. Menn som økte sitt aktivitetsnivå ved alderen 50-60 år fortsatte å ha en høyere mortalitetsrate de første fem år enn menn med uendret høyt aktivitetsnivå. Men etter ti år var den økte aktiviteten assosiert med redusert dødelighet til samme nivå som menn med uendret høyt aktivitetsnivå. Reduksjonen i dødelighet ved økt aktivitet (0,51, 95\% KI 0,26-0,97, sammenliknet med uendret lav aktivitet) var sammenliknbar med den for røykeslutt i forhold til fortsatt røyking $(0,64,0,53-0,78)$.

- Det kjente dose-respons-forholdet viste seg også i denne studien, sier professor
Sigmund Anderssen ved Norges idrettshøgskole. Den er godt gjennomført, og det er tatt hensyn til viktige konfunderende faktorer som fedme, hypertensjon, total kolesterol og sosioøkonomisk status. Stor effekt av å begynne å bli fysisk aktive etter fylte 50 år er et viktig signal for alle godt voksne menn. En like god effekt som for røykeslutt understreker betydningen av fysisk aktivitet $i$ forebygging av tidlig død.

- Byberg og medarbeidere anbefaler minst 30 minutter daglig fysisk aktivitet. Dette er i tråd med norske, europeiske og amerikanske anbefalinger. I Norge anslås det at mer enn $50 \%$ av voksenbefolkningen ikke tilfredsstiller disse anbefalingene, sier Anderssen.

\section{Trine B. Haugen}

trine.b.haugen@hf.hio.no

Tidsskriftet

\section{Litteratur}

1. Byberg L, Melhus H, Gedeborg R et al. Total mortality after changes in leisure time physical activity in 50 year old men: 35 year follow-up of population based cohort. BMJ 2009: 338: b688. 